УДК: 659.182/187

JEL Classification: M31

\author{
T. B. ПITIHOBA, \\ студентка Національного технічного університету \\ "Харківський політехнічниіи інститут", \\ кафедра міжскультурной комунікацій та іноземной мови, \\ група БФ-101м, 6 курс \\ К. В. ХИЖНЯК, \\ кандидат філософських наук, дочент кафедри \\ міжкультурной комунікації та іноземної мови \\ Національного технічного університету \\ "Харківський політехнічний інститут"
}

\title{
Місце та роль промо-акції в системі маркетингових комунікацій підприсмства
}

Проведення промо-акцій вимагас детального опрацювання і постійного контролю, оскільки цей інструмент маркетингових комунікацій здатний вплинути як позитивно, так і негативно на ставления споживача до компаній. У статті визначено поняття промо-акиій, пй сутність та роль у системі маркетингових комунікацій, виведено критерій планування та проведення ефективної промо-акціӥ.

Ключові слова: промо-акція, маркетингові комунікацій, ефективність, інструмент маркетингової комунікацій, споживач, критерій проведення промо-акції.

Постановка проблеми. Сьогодні в якості рекламоносіїв разом із класичними засобами масової інформації виникають та розвиваються нові види реклами. Це пов'язано зі значним зниженням ефективності масових рекламних повідомлень унаслідок стрімкого розвитку традиційних засобів комунікації в системі маркетингу. Наприклад, раніше реклама на телебаченні та радю була досить потужним інструментом для комунікації з клієнтом, але зараз швидко втрачає значимість через надлишок рекламних повідомлень та їх схожість з аналогічними повідомленнями в тій чи іншін̆ сф)ері. Крім того, традиційні канали реклами втрачають ефективність завдяки швидкому розвитку онлайн-медіа.

Оскільки споживач відторгає рекламу масового призначення, фахівцям з маркетингу необхідно працювати індивідуально з кожним клієнтом, використовуючи інструменти комунікації, що здатні привернути та утримати його увагу на продукті, послузі чи нідприємстві в цілому.

Вищезазначене обумовлює актуальність дослідження маркетингових комунікацй як інструменту, здатного визначати ставлення споживача до компанії.

Аналіз останніх джерел та публлікацій. Питання промо-акцій як інструменту маркетингових комунікацій підприємств все докладніше розглядаються в науковопрактичних колах. Теоретичні та практичні аспекти проведення промо-акцій знайшли відображення у працях таких зарубіжних та вітчизняних вчених як С. Семенюк, С. Шпилик [1], О. Краузе [4], А. Дейян, А. Троадек, Л. Троадек [5], М. Стоун, Е. Бонд, Е. Блейк [6], а також А. Марков [7] та ін. Проте дослідження цих авторів в основному торкається питань визначення ефективності проведення промо-акцій, тому постає необхідність використання комплексного нідходу до розкриття сутності концепції проведення ефективної промо-кампанії.

Мета дослідження - визначення важливості проведення промо-акцій для сучасного підприємства та здійснення ефективної комунікації зі споживачами; виведення критеріїв планування та проведення ефективної промо-акції в системі маркетингової комунікації підприємства.

Результати дослідження. Як відомо, перенасичення ринку товарами та послугами призводить до дефіциту споживачів, на знаходження та втримання яких спрямована реклама. Фахівці зазначають, що для досягнення усніху компанії повинні розуміти

(C) Т. В. Пітінова, К. В. Хижняк, 2017 
кожного клієнта, поважати його інтереси та вподобання, цікавитися його поведінкою та передбачати реакцію на будь-які зміни ринку i, найголовніше, ознайомлювати його 3 рекламованим продуктом незалежно від комунікативного каналу. Зі швидким розвитком онлайн-медіа, зокрема Інтернету, традиційні канали втрачають ефективність, тому закордонні фахівці з маркетингу працюють більш індивідуально з кожним клієнтом за допомогою нових інструментів маркетингових комунікацій [I]. Що стосується України, то за результатами соцопитування, проведеного у лютому 20I7 p. компанією Research \& Branding Group ${ }^{1}$, найпопулярнішими 3MI серед українців є все ше залишаються телебачення та Інтернет. Причому телебачення майже в двічі обходить Інтернет за частотою згадування як найбільш використовуване джерело отримання інформації. Інші ЗМІ кардинально відстають від лідерів за цим показником. Але кількість користувачів Інтернету стрімко зростає. Згідно 3 даними дослідження, $58 \%$ українців віддають перевагу ТБ як основному джерелу інформації, 30\% використовують для цього Інтернет, по $2 \%$ - радіо та пресу [2].

Промо-акція не є найновішим інструментом комунікації та просування товару, але при правильній організації та гідній підготовці промо-кампанії можна досягти значних маркетингових та фінансових результатів.

Навіть 3 огляду на зростаючий показник продажів через промо-акції Україиа ще не досягла рівня насичення промо-акціями, який спостерігається в країнах Східної Європи, де через промо-акції проходить від 50 до 60\% продажів категорій товарів, а глибина знижки становить $30 \%$ [3].

Проте враховуючи щомісячне дослідження компанії GfK Ukraine, в якому н̆деться про істотні зміни індексів доцільності великих покупок і очікуваного розвитку економіки країни, промо-кампанії варті уваги при плануванні. Аналітики GfK Ukraine повідомляють, що після незначного падіння в березні $20 \mathrm{I} 7$ р., коли індекс споживчих настроїв погіршився на 0,7 п., в квітні споживчі настрої знову дещо знизилися (на 0,6 п.) і встановилися на позначці 54,9 [4]. Тобто зараз більш рентабельно працювати 3 кожним клієнтом індивідуально, стимулюючи споживача до покупки та покращення показників споживчого настрою. У такій ситуації вкрай важливо правильно організувати промокампанію та обдумати кожну деталь.

Реклама в сучасному світі не тільки інформує потенційного споживача про можливість покупки того чи іншого товару. Вона допомагає розумно здійснювати покупки, повідомляючи про якість, ціну та застосування товару, про які споживачі хочуть знати, перш ніж зробити покупку. Промо-акції ж, що проводяться спільно з іншими методами стимулювання збуту, є важливим способом просування товарів і послуг [5].

Промо-кампанії, безумовно, є важливим і дуже дієвим інструментом сучасного маркетингу. Але, як і у випадку з будь-яким іншим видом маркетингової активності компанії, ця діяльність вимагає обгрунтованого планування, чіткої постановки завдань, а також скрупульозного розрахунку ефективності заходу. Уснішна на перший погляд акція може виявитися збитковою при більш ретельному розгляді.

В умовах жорсткої конкуренції компанії, які проводять активну промо-діяльність та ніклуються про високий рівень мотивації свого торгового персоналу або персоналу роздріб̈ної торговельної мережі, мають значну перевагу перед своїми суперниками. У деяких секторах ринку компанії вже сьогодні змагаються між собою у використанні творчих підходів до проведення акцій, рівні їх технічного забезпечення, ступені зацікавленості торговельного персоналу, який бере в них участь. Сьогодні ринок промо-акцій зростає і розвивається бурхливими темпами. І від того, наскільки уснішно компанія зможе використовувати цей інструмент у своїй діяльності, багато в чому залежить ऑiі завтрашня позиція на ринку [6].

На комунікації в цілому та планування промо-акцій зокрема серйозно впливає процес переходу від масового маркетингу до маркетингу сегментів. Перехід до індивідуального маркетингу сприяє появі нового покоління вузькоспеціалізованих стратегій комунікацій [7].

\footnotetext{
Опитування проводилося в період 1-10 лютого 2017 р. по загальноукраїиській вибірці (за винятком непідконтрольних територій Донецької і Луганської областей, АР Крим, та м. Севастополь). $\mathrm{N}=1800$ осіб. Помилка вибірки склала $\pm 2,4 \%$ при рівні довірчої ймовірності $\mathrm{P}=0,95$
} 
Промо-акція як елемент маркетингової комунікації підприємства $\epsilon$ цілісним комплексом заходів, спрямованим на просування товару чи послуги підприємства, а також на формування позитивного іміджу компанії та інформаційного поля для комунікації виробника і клієнта. Для нідготовки промо-акції необхідно своєчасно залучити багато внутрішніх та зовнішніх структур компанії і координувати їх взаємодію.

Промо-акція - це стимулюючий захід із просування бізнес-продукту на ринку, розрахований на формування інтересу до товару, особи, оргапізації або напряму діяльності [8].

Спеціалыпі пропозиції разом із промо-акціями здатні збільшити купівельну лояльність до продукту, зробити ціну в торговій точці більш конкурентоспроможною відносно інших продуктів, а також стимулювати додатковий імпульс до покупки і залучити нових покупців.

Сучасний маркетинг характеризується трьома змінними, якими необхідно керуватися при розробленні промо-кампанії [9]:

1. Активний розвиток маркетингових каналів

При цьому рекламні кампанії, що орієнтовані на масовість, стають менш ефективними. Споживач не реагус на повідомлення загального призначення, саме тому компанії намагаються забезпечити клієнтам доступ до технологій, що індивідуалізують вибір.

2. 1ндивідуалізація маркетингових каналів.

Більшість веб-сайтів у мережі 1нтернет ідентифікують відвідувача або сам користувач залишає власні дані. Наприклад, на основі пошукових питань на вже верифіковану адресу надсилається певна реклама, шо відповідає запитам.

3. Зміна поведінки споживачів.

Завдяки 1нтернету споживач може у вільному доступі дізнатися інформацію, що його цікавить. Мається на увазі ціна на товар чи послугу, умови його/ії придбання. Споживач має можливість самостійно обирати шляхи отримання інформації, а відтак уникати нав'язування реклами.

Щоб вплинути на споживача, кожна промо-акція має бути основана на тій змінній маркетингу, що відповідає стратегії бренду, на який проводиться промо-акція. Тобто промо-акція повинна враховувати індивідуальні особливості споживача компанії. Необхідно чітко розуміти, хто клієнт, до яких каналів розповсюдження інформації він має доступ, яка його реакція на схожі акції та на комунікативну діяльність компанії в інших їі проявах. Сучасний споживач живе в умовах різномапітності потреб, форм ix задоволення, широких можливостей вибору товарів і послуг. Його купівельна поведінка та, як результат, стосунки з виробником кардинально змінюються. Особливе значення зараз мають для нього особисте позиціонування, процедура вільного вибору, задоволення індивідуального бажання, потреби в співучасті при розробленні нових масових продуктів. Проведення промо-акції вимагає детального опрацювання і постійного контролю, оскільки цей інструмент маркетингових комунікацій здатний вплинути як позитивно, так і негативно на ставлення споживача до компанії.

Формування і кількісне вираження мети майбутньої рекламної акції необхідно здійснювати спільними зусиллями служби маркетингу, відділу продажів і керівництва компанії, щоб виробити актуальну на планований період мету, яка дійсно відповідає потребам підприємства. Необхідно організувати стимулюючу збут промо-акцію при наявності на складі товару в достатній кількості, щоб задовольнити збільшений після 11 проведення попит. Брак продукції в місцях кінщевих продажів через аритмічність роботи виробништва або логістики може викликати негативну реакцію споживачів, які відгукнулися на рекламне повідомлення [10].

Для промо-акцій важливо встановити реальні терміни організації та здійснення рекламної акції. Організаційні терміни - це час, за який можна детально розробити плановану кампанію, скоординувати дії всіх задіяних в ній суб' єктів [11].

За провідною цільовою установкою промо-акції можуть бути різних видів, що визначається проектувальником на етапі аналізу ситуації і залежить від проблем і ресурсів ініціатора або замовника промо-акції [12]. Але проведення будь-якої промо-акції компанією безпосередньо впливає на організацію в цілому, наприклад на позиціонування бренду чи імідж підприємства. 
Найважливішими умовами проведення промо-акції $є$ маркетингові та соціальні суб'єкти (ініціатори, аудиторія), їх статус, настрої (проблеми, інтереси, мотиви, установки, емоціі), матеріальна інфраструктура (приміщення, оформлення, технічні засоби). Однак змістовне наповнення промо-акції як форми маркетингової комунікації здійснюеться шляхом цілеспрямованого комбінування їі подій.

Події, з яких складається промо-акція, виконують різні функції. Вони виступають в якості основного засобу трансляції предмета маркетингової комунікаціі (тобто способу вирішення проблем ініціатора акції). Події забезпечують інтерес аудиторії і ЗМI до промо-акціі, що є основною умовою реалізації ії маркетингового потенціалу. Події можуть бути як самостійним енізодом, так і елементом більш складних форм комунікації [12].

Типові помилки при проведенні промо-акції:

1. Відсутність планування.

Погана організація $є$ результатом недоліків планування: відсутність промоутерів на точці, брак витратних матеріалів, супервайзери не встигають контролювати точки. Наслідки можуть бути різними, але результат зазвичай один - даремно витрачені гроші.

2. Погана нідготовка персоналу.

Персонал - головний ресурс при проведенні промо-акції. Неправильне використання цього ресурсу призводить, в найкращому випадку, до неефективної промо-акції, а в найгіршому - до зменшення продажів. Причина тут може критися у відсутності посадових обов'язків персоналу.

3. Крадіжка.

Уникнути крадіжки можна введенням чіткої системи звітності або збільшенням заробітної плати персоналу, що бере участь у промо-акції.

4. Зовнішній вигляд промоутерів.

Промоутер “зливається" з натовпом при відсутності яскравого, що привертає увагу, одягу. Тобто фірмі-замовнику необхідно продумати зовнішній вигляд промоутера, щоб покупці візуально зрозуміли, представником якої компанії та якого продукту є ця людина. Грамотно вкладені гроші завжди обертаються прибутком.

5. Відсутність зв'язуючої ідеї між промо-кампаніями та іншою рекламною діяльністю стосовно одного продукту.

Компанія має прив'язувати промо-акції, що проводяться або тільки плануються, до іншої рекламної діяльності для посилення загального ефекту.

6. Неправильне визначення цільової аудиторії.

Компанія має докладно вивчити свого споживача та правильно позиціонувати себе щодо цільової аудиторії.

7. Відсутність чітких звітів.

Щоб витрати на промо-акцію були обгрунтованими, компанія має проводити оцінювання обсягів продажів: до акції, під час акції і після неї.

8. Погана організація регіональних промо-акцій.

Компанія має не просто виділити кошти і узгодити формати промо-акцій, що проводяться в регюнах, а ще й забезпечити їх постійний контроль. Без належного контролю і формалізованої звітності кошти найчастіше витрачаються неефективно.

9. Помилки в постановці цілей промо-кампанії.

Це чи не найголовніший пункт планування або проведення промо-кампанії. Неправильно поставлена мета - неефективно проведена акція [13].

Таким чином, важливим завданням для компанії стає ефективне планування промо-діяльності, яке дозволить максимізувати продажі товарів та послуг, посилити цікавість до продукту з боку існуючих споживачів та залучити нових.

Виділимо критерії побудови ефективного промо-плану, які рекомендується враховувати при формуванні стратегіі:

1. Основні цілі і завдання компанії.

2. Основні вподобання щодо продукції у споживача.

3. Переваги споживача.

4. Цілі компанії, основані на перевагах споживачів.

5. Цілі промо-акції. 
6. Вибір механіки промо-акцій в залежності від цілей. Промо-механізм - це спосіб проведення промо-акції, який визначає формат їі реалізації та спеціальні інструменти виконання.

7. Визначення інтенсивності і правильного розподілу періодів проведення промо-акції на ринку.

8. Оцінка всіх проведених промо-акцій для подальшого їх поліпшення.

Для максимізації впливу на споживача можливе одночасне використання кількох каналів розповсюдження інформації. В цьому випадку застосовуються інтегровані програми з використанням мобільних засобів комунікації, зовнішньої реклами, згадування в $3 \mathrm{MI}$.

Розвиток методів стимулювання збуту на сучасному етані впливає на досягнення дедалі більшої кількості маркетингових цілей підприємства. При цьому змінюється роль методів стимулювання. Якщо раніше методи стимулювання, як правило, використовувалися при реалізації обмеженого кола завдань у сфері продажів, то зараз практично немає жодної маркетингової мети, яку не можна вирішити з їх допомогою [14].

В результаті аналізу попередніх видань можемо говорити також про критерії організації уснішної промо-кампанії:

1. Унікальність промо-акції.

Промо-акції індивідуальні для кожної компанії. Навіть якщо промо-акція мала успіх у однієї організації, то при аналогічному продукті чи послузі щось схоже може не спрацювати або нашкодити. Кожну промо-акцію необхідно готувати, починаючи 3 цілей та задач компанії в цілому. Вже на першому етані можна виявити напрямок організації та механіки промо-кампанії.

2. Вплив промо-акції на імідж компанії.

В основному це завдання PR-акцій, спрямовані на формування позитивного іміджу, встановлення довірчих відносин зовнішнього середовища з компанією, досягнення взаєморозуміння і згоди організації та середовища та інші. Проте кожна акція, яку $б$ головну мету вона не мала, при уснішному поширенні інформації обов'язково асоціюється з іменем компанії.

3. Привабливість.

Промо-акція здатна виділити компанію серед конкурентів так, щоб підкреслити іі переваги. Промо-акція - це не що інше, як стимулювання споживачів до вибору товарів саме конкретної компанії, будь то кондитерська крамничка або великий виробник найновішого типу техніки.

4. Довіра.

Тривалі та довірчі відносини з клієнтом мають пріоритетне значення.

Промо-акції можуть бути досить різноманітними за цілями, але завжди необхідно прагнути викликати довіру і лояльність клієнтів, адже завойований один раз клієнт може залучатися до участі в промо-кампаніях багаторазово.

5. Релевантність.

Міра відповідності отримуваного результату бажаному.

6. Увага до деталей.

Краще не робити нічого, ніж нашкодити вже існуючій репутації.

Готуючи проведення промо-акції, необхідно продумати кожен крок і кожну деталь. Якшо клієнт залишився незадоволеним, про це дізнаються втричі більше людей, ніж в ситуації, коли його все влаштувало.

7. Простота розуміння промо-акцій.

Не потрібно робити правила промо-акції досить складними. Часто проведені заходи $€$ неефективними через те, що неправильно або недостатньо чітко сформульована ідея самої рекламної кампанії. Простота - це гарантія того, що первинний інтерес учасника до акщії не буде втрачено.

8. Нестандартність.

Це головний елемент сучасної промо-акції. Нестандартність - це врахування конкретно поставленої задачі, особливостей ринку, специфіки компанії і продукції, яку вона пропонує. Створити незвичайний імідж товару/компанії означає привернути увагу споживачів і викликати їх інтерес. 
Враховуючи темп розвитку медіа-сфери та маркетингу в цілому, фахівцям необхідно швидко реагувати на зміни, надаючи компаніям все нові способи контакту 3 аудиторією. Чим яскравіший рекламний проект чи акція, тим більша ймовірність, що споживачі до нього швидко звикнуть, а це призведе до зменшення ефективності маркетингових кампаній і зниження обсягів продажів. Сьогодні доцільно використовувати методи прямого впливу на поведінку споживачів, i промо-акції є одним із таких методів. Виведені критерії планування та організації промо-кампанії дають можливість налагодити зв' язок клієнта 3 підприємством і у такий спосіб збільшити обсяг продажів та покращити його фінансові показники.

Висновки. Важливим завданням для компанії стає ефективне планування промодіяльності, яке дозволить ій максимізувати продажі і навіть завоювати нового споживача.

Промо-акції - це дуже ефективний спосіб заявити про свою компанію, товар чи послугу, донести до споживачів інформацію про виняткові якості їі продукції, переключити увагу покупців із пропозицій конкурентів на конкретну продукцію компанії i, врешті-решт, збільшити продажі та прибутки.

В ході дослідження виявлено, що розроблення ефективної промо-акції потребує творчого нідходу з урахуванням позиціонування марки й індивідуальних інтересів та особливостей кожного споживача. Сформовано критерії оцінювання ефективної промо-кампанії: унікальність, привабливість, релевантність, простота розуміння акції, довіра та бажання розповісти про акцію друзям.

\section{Список використаних джерел}

1. Семенюк С., Шпилик С. 1нтерактивний маркетинг: стан розвитку в Україні // Галицький економічний вісник. 2012. № 2 (35). С. 87-95.

2. RBG: самыми популярными среди украинцев СМИ остались ТВ и Интернет [Электронный ресурc]. URL: http://rb.com.ua.

3. Частка промо продажів в Україні зростає [Електронний ресурc]. URL: http://www. nielsen.com/.

4. GfK: в апреле потребительские настроения украинцев несколько ухудшились [Электронный ресурс] // Ассоциация Ритейлеров Украины, 2017. URL: https://rau. ua/ekonomika/.

5. Калиева О. М., Михайлова О. П. Эффект совместного действия рекламы и стимулирования сбыта в розничной торговле // Вестник Оренбургского государственного университета. 2014. № 4. С. 168-172.

6. Василенко Е. И. Торговый маркетинг. Ростов-на-Дону, 2010. (Институт управления, бизнеса и права).

7. Краузе О. 1нтегровані маркетингові комунікації підприємства // Соціальноекономічні проблеми і держава. 2008. № 1.С. 104-110.

8. Дейян А., Троадек А., Троадек Л. Стимулирование сбыта и реклама на месте продажи. М.: Прогресс-Универс, 1994. 190 с.

9. Стоун М., Бонд Е., Блейк Е. Прямой интерактивный маркетинг. М: Баланс Бизнес Букс, 2005. $552 \mathrm{c}$.

10. Олейник К. Создание эффективной промо-акции как инструмента стимулирования продаж // Управление продажами. 2012. № 4. С. 50-57.

11. Шушкевич С. В. Рекламные акции: взгляд изнутри // Маркетинговые коммуникации. 2006. № 6. С. 360-367.

12. Марков А. П. Проектирование маркетинговых коммуникаший. СПб.: Издание Санкт-Петербургского гуманитарного университета профсоюзов, 2005. $398 \mathrm{c}$.

13. Стерхова С. А. Новый продукт: ключевые факторы успеха // Инновации № 1. 2006. № 88. C. 58-63.

14. Романенкова О. Н. Методы планирования продаж и составления трейдмаркетингового бюджета // Вектор науки ТГУ. 2012. С. 141-144. 
Т. В. ПИТИНОВА,

студентка Национального технического университета

«Харьковский политехнический институт», кафедра межкультурной коммуникации и иностранного языка, zpynna $Б \Phi-101 \mathrm{M}, 6$ курс

К. В. ХИЖНЯК, кандидат философских наук, дочент кафедры межскильтурной коммуникауии и иностранного языка

Национального технического университета «Харьковский политехнический институт»

\section{Место и роль промо-акции в системе маркетинговых коммуникаций предприятия}

Проведетие промо-акции требует детальной разработки и постоянного контроля, поскольку этот инструмент маркетинговых коммуникаций способен повлиять как положсительно, так и отрицательно на отноиение потребителя к компании. B статье определено понятие промо-акции, ее сущность и роль в системе маркетинговых коммуникачий, выведены критерии планирования и проведения эффективной промо-акциии.

Ключевые слова: промо-акция, маркетинговые коммуникации, эффективность, инструмент маркетинговых коммуникаций, потребитель, критерии проведения промо-акции.

T. B. PITINOVA, Six-Year Student,

Kharkiv National Technical University "Kharkiv Politechnic Institute",

Department of Cross-Cultural Communication and Foreign Language, group $Б \Phi-101 \mathrm{M}$

K B. KHYZHNYAK,

PhD (Philosophy), Associated Professor,

Department of Cross-Cultural Communication and Foreign Language,

Kharkiv National Technical University "Kharkiv Politechnic Institute"

\section{Position and Role of Promotion in the Marketing Communication System at Company Level}

New types of advertizing have appeared apart from classical mass media due to the shrinking effectiveness of traditional advertizing messages. Promotions are not a brand new instrument for communicating and promoting goods and services to the market, but once organized and in a correct manner, they will be capable to bring success and good financial returns. Each promotion needs to be thoroughly elaborated and permanently controlled, being an instrument of marketing communications capable to have either positive or negative implications for the consumer attitude to a company. The objective of the study is to demonstrate the importance of promotions for company performance and effective communication with customers; to define the criteria for planning and organization of an effective promotion as part of marketing communication at company level. The essential meaning of promotion and its role in the system of marketing communications is highlighted. The most common mistakes in organizing promotions are shown; the criteria for effective planning of promotion campaign and the criteria for successful organization of a promotion are given.

Keywords: promotion, marketing communications, efficiency, instrument of marketing communications, consumer, criteria of implementing promotion.

\section{Посилання на статтю:}

Пітінова Т. В., Хижняк К. В. Місце та роль промо-акції в системі маркетингових комунікацій підприємства // Науковий вісник Національної академії статистики, обліку та аудиту: зб. наук. пр. 2017. №3. С. 65-71. 